\title{
Women and glass ceilings in the construction industry: a review
}

\section{Las mujeres y los techos de cristal en la industria de la construcción: una revisión}

DOI: $10.46932 / \mathrm{sfjdv2n3-072}$

Received in: May 1st, 2021

Accepted in: Jun 30th, 2021

Urpi Barreto Rivera
Máster en Planificación y Gestión en la Ingeniería Civil
Departamento Académico de Ingeniería Civil. Universidad Nacional de San Antonio Abad del Cusco.
Av. de La Cultura 773, Cusco, Perú
E-mail: urpi.barreto@ unsaac.edu.pe
Yasser Abarca Sánchez
Magister en administración estratégica de negocios
Urb. Ucchullo Grande P-6, Cusco, Perú
E-mail: yabarca@ continental.edu.pe
Juan Pablo Mellado Pagan
Magister en Administración Estratégica de Empresas

Departamento Académico de Ciencias Administrativas. Universidad Nacional de San Antonio Abad del Cusco

Urb. Túpac Amaru, i-1-11, San Sebastián, Cusco. Perú

E-mail: jpmellado@pucp.pe

Walter Carpio Ballón

Maestro en Gerencia de la Construcción.

Departamento Académico de Ingeniería Civil. Universidad Nacional de San Antonio Abad del Cusco. Av. de La Cultura 773, Cusco, Perú

E-mail: wcarpiob@gmail.con

\section{Orlando Barreto Jara}

Maestro en Economía. Mención Gestión Pública y Desarrollo Regional

Departamento Académico de Ingeniería Civil. Universidad Nacional de San Antonio Abad del Cusco. Av. de La Cultura 773, Cusco, Perú

E-mail: urpi.barreto@unsaac.edu.pe

\section{Raúl Abarca Astete}

Doctor en administración.

Departamento Académico de Ciencias Administrativas. Universidad Nacional de San Antonio Abad del Cusco

Av. de La Cultura 773, Cusco, Perú

E-mail: raul.abarca@unsaac.edu.pe

\begin{abstract}
At the global level, the representation of men and women in the hierarchical scale within the labor market manifests itself unevenly, generally concentrating the occupations of women in the lower scales. An
\end{abstract}


explanation for this phenomenon is the glass ceilings, invisible barriers faced by women during the development of their careers, which do not allow them to progress towards higher positions. This phenomenon is not indifferent to the construction sector, where a relatively unknown situation is observed for women; This situation has prompted a series of investigations with the shared concern to identify the obstacles that prevent women from developing in the construction sector. This article carries out a bibliographic review of the subject using the technique of documentary analysis, which has made it possible to obtain the state of the art and identify the dimensions that make up glass ceilings in the construction sector. The results point to the presence and constancy of glass ceilings due to the nature of the sector, the walls that begin in the hiring activity and persist throughout all professional development; thus, perpetuating inequalities between women and men from one generation to another within the sector.

Keywords: Labor segregation, construction industry, gender, glass ceilings.

\section{RESUMEN}

A nivel mundial, la representación de hombres y mujeres en la escala jerárquica dentro del mercado laboral se manifiesta de forma desigual, concentrando generalmente las ocupaciones de las mujeres en las escalas inferiores. Una explicación de este fenómeno son los techos de cristal, barreras invisibles a las que se enfrentan las mujeres durante el desarrollo de sus carreras, que no les permiten progresar hacia posiciones más altas. Este fenómeno no es indiferente al sector de la construcción, donde se observa una situación relativamente desconocida para las mujeres; esta situación ha impulsado una serie de investigaciones con la preocupación compartida de identificar los obstáculos que impiden a las mujeres desarrollarse en el sector de la construcción. En este artículo se realiza una revisión bibliográfica del tema mediante la técnica del análisis documental, que ha permitido obtener el estado del arte e identificar las dimensiones que conforman los techos de cristal en el sector de la construcción. Los resultados apuntan a la presencia y constancia de los techos de cristal debido a la naturaleza del sector, muros que se inician en la actividad de contratación y persisten a lo largo de todo el desarrollo profesional; perpetuando así las desigualdades entre mujeres y hombres de una generación a otra dentro del sector.

Palabras clave: Segregación laboral, industria de la construcción, género, techos de cristal.

\section{INTRODUCTION}

Labor segregation based on gender is present in all organizations and occupations, where men occupy the highest paid and most prestigious jobs, and the highest positions of organizational power (Williams, 1995). A large body of research has been conducted that recognizes the ways in which labor sex segregation is reinforced and places restrictions on women's careers, as well as gender inequality in the workplace, including unequal wages, reduced job opportunities, promotion and high professional mobility (Maume Jr, 1999; Okamoto \& England, 1999).

The construction sector is not immune to this phenomenon, which offers a relatively inhospitable climate for women (Graham \& Hotchkiss, 2003); since it is a sector typically known as non-traditional for women; Along these lines, various researchers have conducted studies in the different states of the European Union and the United States (Andrew R J Dainty et al., 2005; Simon, 2013), Singapore (Yean Yng Ling \& Pei Poh, 2004), South Africa (Madikizela \& Haupt, 2010), Nigeria (John Kolade \& Kehinde, 2013), Turkey (Arslan \& Kivrak, 2004), Thailand Tailandia (Kaewsri \& Tongthong, 2014), Peru (Barreto 
et al., 2017) and Malaysia (Jaafar et al., 2014). In view of the large amount of knowledge generated worldwide, this research updates and systematizes the state of the art of said investigations and identifies the dimensions of the Glass Ceilings.

To achieve the objectives, a bibliographic review was carried out, using the technique of documentary analysis, systematizing academic articles that address the subjects of interest. The Scopus database has been used. To carry out the search, the keywords were used: women, construction industry, career, glass ceiling and barriers. The search has been limited to engineering and business, among which 326 articles were obtained, of which an analysis was made with the software Vosviewer in order to build bibliometric networks around the subject.

The research addresses issues entering the world of work and development in it, it is noted that there is a weak attracting talent to the sector and a poor understanding of it. Likewise, the recruitment phases, the culture and the work environment of the organizations have androcentric criteria. When women manage to enter and develop in the sector, they are assigned secondary jobs, where sexual harassment at work is imminent, in the same way women lack access to formal and informal networks at work, dominated by a masculine culture in which the family-work conflict is completely ignored.

\section{MATERIALS AND METHODS}

Labor segregation based on gender refers to the unequal presence of men and women who work in sectors differentiated according to their gender (horizontal segregation) or who occupy positions lower in the hierarchical scale (vertical segregation). One factor that explains gender inequality is the consequence of "glass ceilings", which are understood as invisible barriers faced by women during the development of their professional careers, which do not allow them to progress towards higher positions on the scale hierarchical.

In the construction sector, the existence and persistence of glass ceilings in the professional development of women is a fact (Heredia, 2004), the nature of the sector confirms the existence of these mechanisms, since the barriers begin in the hiring process (McKeen \& Burke, 1994; Morgan, 1992) where recruitment procedures and methods are carried out with androcentric criteria (Amaratunga et al., 2006; Fielden et al., 2000); Likewise, when the professional development of women engineers is compared with that of men, it can be observed that women become stagnant in their organizational hierarchies (A R J Dainty et al., 2000; Andrew R J Dainty et al., 2000). In addition, women entering the construction industry, occupying professional positions, offer to fill specialist technical positions rather than general management positions (Bennett et al., 1999). 
Women who develop in non-traditional industries, such as the construction sector, are more likely to have a better expectation of money, considering that the choices they make are due to individual competencies, motives and contexts (Anna et al., 2001). However, the nature of field work constitutes a major obstacle for women (A. R. Dainty \& Lingard, 2006), where they do not acquire the kind of professional experience that can lead to promotion (Amaratunga et al., 2006). This greatly harms women because it reduces their opportunities and generates a wage gap with men, and this leads to lower social and economic status of the same. Thus perpetuating, in the construction sector, inequalities between women and men from one generation to the next.

The bibliometric study has allowed the study and analysis of scientific activity regarding research related to women and glass ceilings in the construction sector, Figure 1 shows the analysis of the Scopus bibliographic database from 1983 to the year 2018. There is a significant growth in research in recent decades, the growth trend demonstrates the shared concern of researchers regarding women and glass ceilings; however, the number of investigations is still minimal.

Figure 1. Growth in the number of investigations related to women and glass ceilings in construction in recent decades

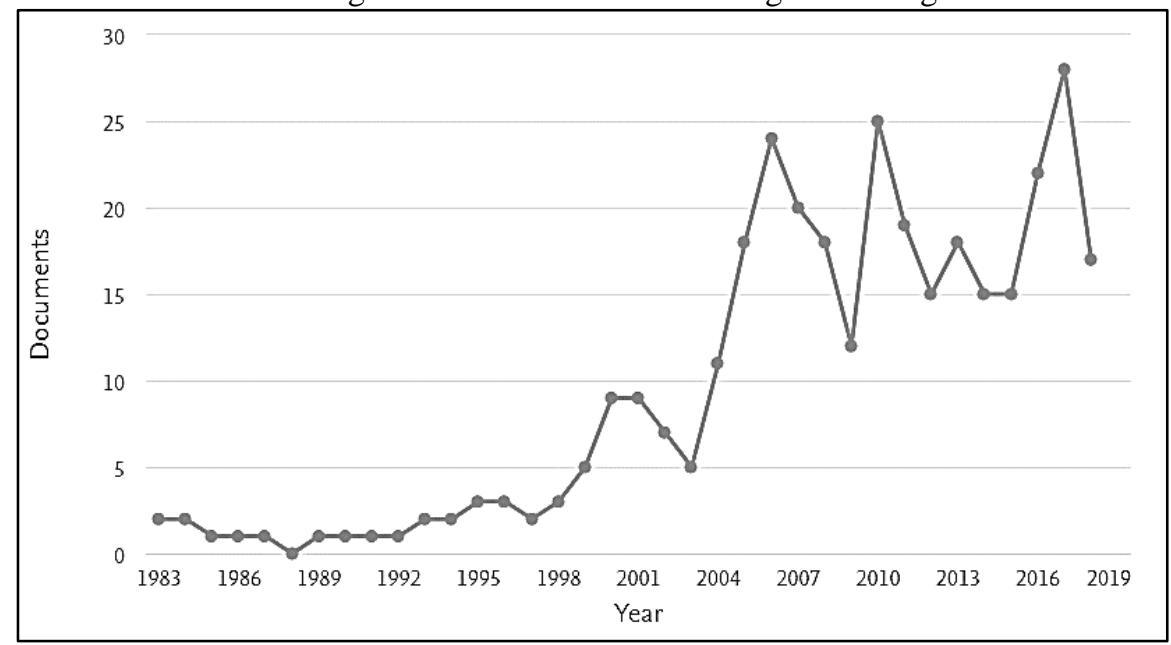

Using the VOSviewer program, a relationship was generated between the countries that carry out the most research on the topic developed, a relationship that is presented in Figure 2. It is observed that the United Kingdom, the United States and Australia are the countries that are leading the investigations. It is evident that developed countries see women as a valuable resource in the construction sector that must be developed in their entire professional field. 
Figure 2. Research interaction network on women and glass ceilings in construction at the country level

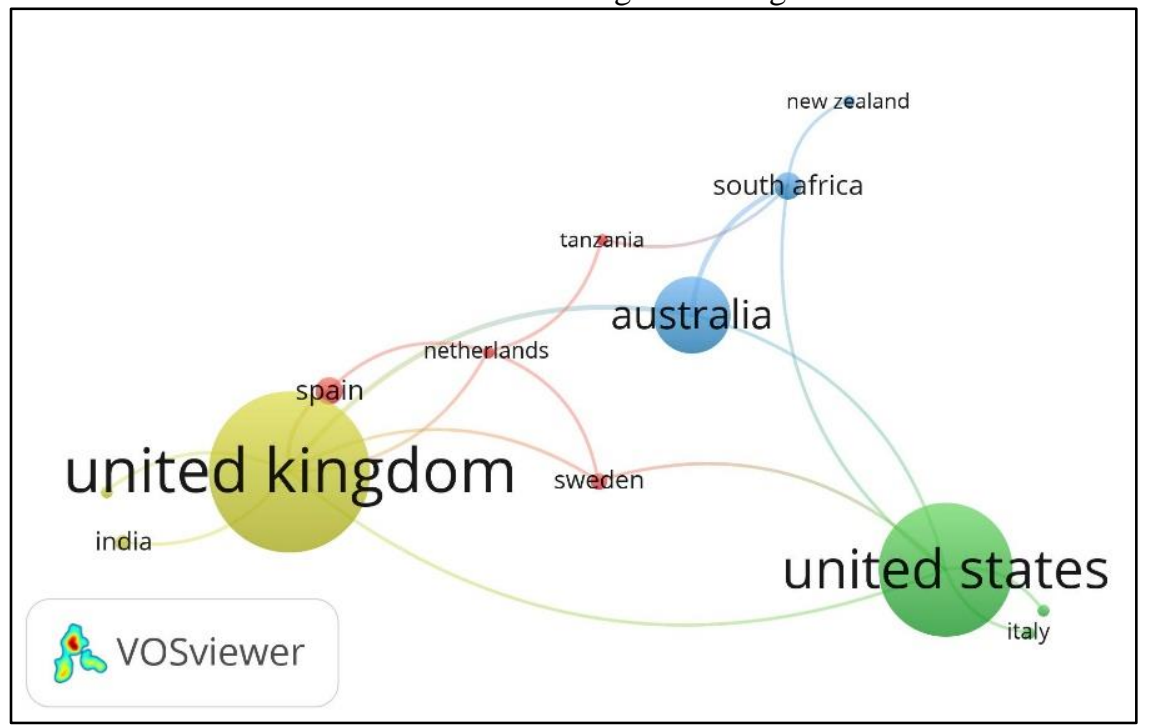

\section{GLASS CEILINGS}

Engineering is considered as a traditionally masculine, hard, heavy, dirty and machinery-oriented profession (McIlwee \& Robinson, 1992; Ogunlana et al., 1993), any entry of women into this profession is considered an attempt to cross the barrier of gender (Jaiswal, 1993), a fact for which there are fewer women studying engineering and developing their profession (Hughes, 1994), and the few women who practice the profession face a powerful gender segregation in terms of hierarchical positions (Wirth, 2001). To explain these inequalities, an important factor is the glass ceilings, a syndrome that hinders the attraction and professional development of women, especially when compared with the total number of women in the workforce (Amaratunga et al., 2006; Ginige et al., 2007; Ling \& Leow, 2008), and it is attributed to structural factors, characteristic of culture, the difficulties of women in accessing the higher positions of the social scale, although their access to them is legally recognized (Helen Lingard \& Lin, 2004); that is, it is such a subtle barrier that it is invisible, implicit but impenetrable that it prevents women from reaching parity with their male counterparts at the highest levels of the hierarchical scale.

There is a series of investigations that support the existence and persistence of glass ceilings in the professional development of women in the construction sector. In principle, the nature of the sector allows the existence of such mechanisms; barriers begin in the hiring process, which is plagued by prejudice and discrimination by the employer (McKeen \& Burke, 1994; Morgan, 1992). Although the terms and conditions within the construction industry are generally poor, regardless of gender (Amaratunga et al., 2006), recruitment procedures and methods continue to have androcentric criteria (Amaratunga et al., 2006; Fielden et al., 2000) which does not allow many women to apply for new positions in organizations (Andrew R J Dainty et al., 2000). It is also suggested that a hiring criterion is that women usually do not have a good training and do not have the necessary skills and training (Gale \& Skitmore, 1990; McKeen 
\& Burke, 1994), however this is not more than a resistance on the part of construction companies to recognize women as an important source of the labor force (Gann \& Senker, 1998).

Professional women who have managed to enter the construction industry have generally stagnated at the hierarchical level (A R J Dainty et al., 2000; Andrew R J Dainty et al., 2000), there are fewer women than men in places where decisions are made and in those with professional prestige, and the majority of women who work in the construction industry perform administrative, technical, professional work, personal and protection services (Clarke et al., 1999), although women tend to be more ambitious and with high academic achievement, lack of development quickly leads to dissatisfaction (Andrew R J Dainty et al., 2000).

One of the factors of rise in the organizational hierarchy is the time to work in the sector, since the permanence in certain functional areas and implementation of plans for executive development provide preparing people to make senior appointments (Amaratunga et al., 2006). Many women have limited access to the wide range of experiences and development activities needed to advance despite having appropriate educational qualifications (Wernick, 1994). In addition, in the case of promotions, members are often "invited" to apply, thus perpetuating the typical scenario of jobs for men (Evetts, 1998). However, and increasingly, in universities it is observed the admission of academics to "masculinized" departments such as some engineering, exact and natural sciences (Reyes \& Delgado, 2021)

Although female representation in managerial positions is increasing little by little, the phenomenon of women being restricted to the lower levels, under the glass ceiling effect continues in many countries (Ginige et al., 2007). A clear example of this is evidenced in Thailand where there is a slow advance in the careers of women, who finally leave the industry to work in other fields (Hossain \& Kusakabe, 2005), thus also in Singapore there is explicit gender discrimination that causes manifest obstacles for women seeking advancement in leadership roles in the industry (Toor \& Ofori, 2010).

\section{GLASS CEILING DIMENSIONS}

The construction industry employs workers in two categories: (i) managers and professionals who plan, organize, advise on specialized functions or field activities involved in project execution, and (ii) construction trades, who build, install, complete, maintain and repair internal and external structures of domestic, commercial and installation buildings and civil construction (Fielden et al., 2000). This article develops the dimensions of glass ceilings faced by workers in the first category.

- Entry into the labor market

Social practices take a number of forms, both open (low pay and authority status) and covert (images of domesticity and sexuality), which serve to restrict female opportunities, both in recruitment 
and promotion, thus reinforcing impotence. organizational of women. Likewise, there are differences between men and women on the way in which domestic production affects income from self-employment, because women are restricted by the increase in domestic work and raising children, while men Selfemployed people do not have this type of restriction at a minimum level (Hundley, 2001).

- Recruitment and retention criteria

Many women after finishing their university studies do not enter to work in the industry due to the poor image, they have of it and the inherent difficulties of working in such a male-dominated environment (Andrew R J Dainty et al., 2000). Informal practices are allowed in the hiring process; such as advertisements and brochures describing male values and interests, unstructured interviews, discriminatory selection criteria, and sexist attitudes (Fielden et al., 2001), "disorderly and inefficient" methods that lead to unequal access subject to stereotypes, prejudices and questionable "qualifications". Which may mean that companies bypass individuals with education, interest, and potential, especially for managerial and executive responsibility (Wernick, 1994).

- Work environment

The negative image and culture of the industry limit the attractiveness of the sector for women (Fielden et al., 2001; Gale, 1994). The construction industry shows a macho culture where relationships are characterized by argument, conflict and crisis (Gale, 1994). As a result, collaborators discover that they are exposed to an extremely hostile environment. In this male-dominated profession, stereotypes are added about the nature of the profession and the professionals themselves (Langford et al., 2014).

- Job development

Tokenism refers to the practice of making superficial and small concessions towards a segregated group, with little or no influence on modifying the status quo (Kanter, 1977), in the construction sector, the objective of carrying out tokenist concessions is to deflect or refute the accusations of discrimination against them, especially regarding the entry into the labor market of women in the construction sector; that is, quotas help women to overcome the entry barrier, but they do not help women to develop a career in the organization or even to remain employed (Hossain \& Kusakabe, 2005).

- Secondary works

In the construction industry, women are more likely to find themselves in personnel-related roles (human resources, communications, etc.) rather than in service delivery and production roles. Data on women working at the operational level are rare (Jaafar et al., 2014), and those who enter these positions focus on technical specialist positions rather than general managerial positions (Bennett et al., 1999; Ellison, 2001). In some organizations, the differences between male and female workers regarding the interference of work with household management activities are almost imperceptible; however, this aspect 
is due to the fact that women perform less demanding functions such as secretaries and administrative assistants, therefore they are underrepresented in roles associated with higher time-based demands in the construction and general engineering (H. Lingard \& Francis, 2004). As there are few women in the sector, they often do not have the necessary contacts and continually experience difficulties in finding employment, which means that they are more likely to seek and accept jobs in other subsectors (Andrew R J Dainty et al., 2001; Kramer \& Lambert, 2001). For example, in Thailand and Bangladesh, female engineers complained about the jobs to which they were assigned: most of the time for assistant, public relations, and non-project work (Hossain \& Kusakabe, 2005). However, there are other areas in which women feel reaffirmed and valued as employees, such is the case of civil engineering professors (Ortiz et al., 2014), which means that the diversification and appreciation of women is necessary.

- Accumulation of professional experience

The nature of field work constitutes a great barrier for women (A. R. Dainty \& Lingard, 2006), this is necessary but rarely developed and therefore women lack this type of professional experience that leads to promotion (Gayani Fernando et al., 2014). Older women who have achieved a good position in small construction companies are the product of circumstances and chance choices(Lu \& Sexton, 2010). This translates into gender-differentiated career opportunities that have an inevitable consequence of the high turnover of female personnel in construction companies (Davidson \& Cooper, 1992).

- Informal networks

Access to senior development opportunities is often gained through informal mentors and networks. However, women tend to lack access to informal networks that offer information about these types of opportunities (Townley, 1989). Many women face discrimination and harassment, and are excluded from social circles recognized as essential for career development in such informal work cultures; this is not the case with their male counterparts, who do not experience exclusion from these network groups redes (Andrew R J Dainty et al., 2000). In other words, women who work in the construction sector either have to be sociable to adapt or are otherwise marginalized, discouraged and eventually expelled (Greed, 2000). Additionally, women are less likely to have a mentor to point out their potential and provide the necessary support to ensure success.

- Organizational culture

Inequality in the workplace is a common denominator in the construction sector (Bagilhole et al., 2002; Byrne et al., 2005; A. R. Dainty \& Lingard, 2006; Elvitigala et al., 2006; Gale, 1994; Greed, 2000; Helen Lingard \& Lin, 2004; Madikizela \& Haupt, 2010; Whittock, 2002). Lack of opportunity to pursue job-based training, production-based salary systems, informal hiring methods, lack of proactive application of equal opportunity policies (Byrne et al., 2005), structure organization (A. R. Dainty \& 
Lingard, 2006), male-dominated training courses (Amaratunga et al., 2006; Fielden et al., 2000) and the operation of corporate policies and procedures result in differentiated opportunities men and women. Organizational culture is closely linked to and influenced by external factors, such as sociocultural norms and ideologies, which lead to specific behaviors within an organization (Fagenson, 1990; Flanders, 1994; Maddock, 1999). Organizational practices are a way of perpetuating unequal gender divisions at work and deepening sexual segregation in the workplace (Acker, 1998; Collinson \& Hearn, 1996; Andrew R J Dainty et al., 2000; Martin, 1996; Mcllwee \& Robinson, 1992), these organizational practices institutionalize men's privileges (Martin, 1996). The gender gap in the construction industry is influenced by social norms and by the characteristics of the industry itself; where women earn less than men (Amaratunga et al., 2006).

- Family - work conflict

The construction sector presents its workers with a high conflict between work and family responsibilities (Amaratunga et al., 2006; Bagilhole et al., 2002; Byrne et al., 2005; A. R. Dainty \& Lingard, 2006; Elvitigala et al., 2006; Fielden et al., 2000; Gale, 1994; Greed, 2000; Helen Lingard \& Lin, 2004; Madikizela \& Haupt, 2010; Whittock, 2002). This is defined as a form of inter-role conflict whereby work and family cannot be satisfied at the same time and is a continuous problem for women with professional aspirations (Wentling, 1996). Organizations tend to treat family and work as completely independent factors (Fielden et al., 2000), and although men and women have to balance the demands of work and family life, as a general rule, it is women who they tend to take on most of the family responsibilities and household responsibilities as their own, even when they work full time and share their lives with colleagues who have a positive attitude towards domestic collaboration (Higgins et al., 2000). Long working hours, the requirements for international experience and for obtaining new academic qualifications represent an impossible combination between a fulfilling family life and a successful career (Andrew R J Dainty et al., 2000), as this requires a lot of effort, a great personal organization and a heavy load of additional stress. These circumstances force women to decide between having a family and developing lower expectations regarding work experience (Helen Lingard \& Lin, 2004). This translates into a cyclical development between personal and professional, as their career patterns tend to move through phases in which other aspects of life take precedence (Bennett et al., 1999).

Women are still looking for rewarding engineering professions, trying to find balance with families and leisure activities, however, not seeing this aspect in a significant amount is an indication of the great difficulty of doing so, therefore, Reconciling the demands of the engineering profession with the rest of life requires careful planning to achieve an adaptation that, for many, appears to be barely achievable (Watts, 2009). Women who have achieved greater development in their careers are generally single, 
childless, or divorced; that is, they have essentially sacrificed the traditional family in favor of professional advancement (Guillaume \& Pochic, 2009). Difficulties are exacerbated when it comes to managerial activities that involve prolonged dedication and a high availability of displacement. Although part-time work is a good option, there are few opportunities in the construction sector (Evetts, 1998).

- Male culture

Long working hours, competition, independence, full-time work, rewards, and expectations of career success are paramount in the construction industry, all known as typically male values (Davey et al., 1998). The construction culture is masculine and inherently conflictive (Gale, 1994), where conventional images of masculinity are clearly associated with success (Rapoport et al., 2002) and with an extremely macho, hostile and discriminatory culture towards women (Bagilhole et al., 2002). That is, those who have chosen this culture have a great interest in promoting and maintaining that culture and in resisting change (Gale, 1994), this macho environment is expressed in more disturbing terms and sexual harassment within the construction industry. Various forms of masculinity that share common content, such as the characteristics of paternalism or authoritarianism, competition or entrepreneurship and professionalism, exclude women in one way or another, or restrict their ability to exercise power in organizations (Collinson \& Hearn, 1994). Thus, women who seek to enter male-dominated cultures have to act like men to be successful, if they do not adapt to the culture they have to withdraw from the sector or they can remain in the culture, without behaving like men, but working in lesser positions (Davidson \& Cooper, 1992).

\section{DISCUSSION}

Research shows that the construction industry is losing some of its valuable human capital, and a lot of knowledge is not flowing from universities to industry. The most serious problems reflected point to a low entry into engineering studies, understood because construction jobs are stressful, expensive and demanding; In other words, the image has a negative effect on the level of female employment in the construction industry, as well as the weak attraction of talent. On the other hand, when women manage to enter the world of work, there are other types of barriers such as androcentric recruitment criteria and work culture. Women, who despite all the above barriers, manage to enter the world of work, face much greater glass ceilings, such as family-work conflict, access to secondary jobs, sexual harassment at work, organizational culture and male culture.

The findings underscore the importance of the organization's policy, practices and culture in creating an enabling environment for women. Working conditions in the construction industry can be improved by reducing the workload, making the work environment less stressful, and shortening working 
hours. Also, organizations could create their own culture and practices that do not necessarily reinforce social expectations of gender. In the same way, the support networks that are key to women being successful in the field and the attitudes and perceptions of the existing construction industry must be adjusted to accommodate and accept women in the field.

Organizations could be more responsive to work and family demands and rethink career and work models for the men and women of this new generation. Employers must also be prepared to adopt work practices to allow employees to be successful in their work and family responsibilities simultaneously. Likewise, companies must formalize their commitment to equal opportunities to project an image that is sensitive to women's problems. In this way, measures to alleviate labor problems will not only attract and retain top talent in construction, but will also ensure that knowledge flows and grows from universities to and remains in industry.

\section{CONCLUSIONS}

A review of the literature has revealed that labor segregation based on gender is fully in force in the construction sector. Vertical segregation understood through glass ceilings has been studied, the amount of literature and research found worldwide is extensive, with the shared concern of researchers to highlight the barriers that women face worldwide and propose a series of options to find the factors that determine glass ceilings for women to develop in the construction industry. The present research has allowed to determine the dimensions of the glass ceilings, such as the weak attraction of talent, little initial understanding of the industry, androcentric criteria of recruitment and retention, culture and work environment. Also, during their work development, dimensions such as secondary jobs, sexual harassment at work, informal networks, organizational culture, family-work conflict and male culture have been identified. 


\section{REFERENCES}

Acker, J. (1998). The future of 'gender and organizations': connections and boundaries. Gender, Work \& Organization, 5(4), 195-206.

Amaratunga, D., Haigh, R., Shanmugam, M., Lee, A. J., \& Elvitigala, G. (2006). Construction industry and women: A review of the barriers. Proceedings of the 3rd International SCRI Research Symposium.

Anna, A. .., Chandler, G. N., Jansen, E., \& Mero, N. P. (2001). Women Business Owners in Traditional and Non-Traditional Industries. 9026(98), 4047-4048. https://doi.org/10.1016/S0140-6736(11)60351-6

Arslan, G., \& Kivrak, S. (2004). The lower employment of women in Turkish construction sector. Building and Environment, 39(11), 1379-1387.

Bagilhole, B. M., Dainty, A. R. J., \& Neale, R. H. (2002). A woman engineer's experiences of working on British construction sites. International Journal of Engineering Education, 18(4), 422-429.

Barreto, U., Pellicer, E., Carrión, A., \& Torres-Machí, C. (2017). Barriers to the Professional Development of Qualified Women in the Peruvian Construction Industry. Journal of Professional Issues in Engineering Education and Practice, 143(4), 5017002.

Bennett, J. F., Davidson, M. J., \& Galeand, A. W. (1999). Women in construction: a comparative investigation into the expectations and experiences of female and male construction undergraduates and employees. Women in Management Review, 14(7), 273-292.

Byrne, J., Clarke, L., \& Van Der Meer, M. (2005). Gender and ethnic minority exclusion from skilled occupations in construction: a Western European comparison. Construction Management and Economics, 23(10), 1025-1034.

Clarke, L., Pedersen, E. F., \& Wall, C. (1999). Balancing acts in construction: A study of two women painters in Denmark and Britain. Nora: Nordic Journal of Women's Studies, 7(2-3), 138-150.

Collinson, D., \& Hearn, J. (1994). Naming men as men: Implications for work, organization and management. Gender, Work \& Organization, 1(1), 2-22.

Collinson, D., \& Hearn, J. (1996). Men as managers, managers as men: Critical perspectives on men, masculinities and managements. Sage.

Dainty, A. R., \& Lingard, H. (2006). Indirect discrimination in construction organizations and the impact on women's careers. Journal of Management in Engineering, 22(3), 108-118.

Dainty, A R J, Neale, R. H., \& Bagilhole, B. M. (2000). Comparison of men's and women's careers in UK construction industry. Journal of Professional Issues in Engineering Education and Practice, 126(3), $110-115$.

Dainty, Andrew R J, Bagilhole, B. M., \& Neale, R. H. (2000). A grounded theory of women's career under-achievement in large UK construction companies. Construction Management \& Economics, 18(2), 239-250.

Dainty, Andrew R J, Bagilhole, B. M., \& Neale, R. H. (2001). Male and female perspectives on equality 
measures for the UK construction sector. Women in Management Review, 16(6), 297-304.

Dainty, Andrew R J, Qin, J., \& Carrillo, P. M. (2005). HRM strategies for promoting knowledge sharing within construction project organisations: a case study. In Knowledge management in the construction industry: A socio-technical perspective (pp. 18-33). IGI Global.

Davey, C., Davidson, M., Gale, A., Hopley, A., \& Rhys Jones, S. (1998). Building equality in construction: Good practice guidelines for building contractors and housing associations. UMIST/DETR.

Davidson, M. J., \& Cooper, C. L. (1992). Shattering the glass ceiling: The woman manager. Paul Chapman Publishing.

Ellison, L. (2001). Senior management in chartered surveying: where are the women? Women in Management Review, 16(6), 264-278.

Elvitigala, G., Amaratunga, D., \& Haigh, R. (2006). The impact of culture on career development of women in construction. Proceedings of 6th International Postgraduate Research Conference in the Built and Human Environment.

Evetts, J. (1998). Managing the technology but not the organization: Women and career in engineering. Women in Management Review, 13(8), 283-290.

Fagenson, E. A. (1990). At the heart of women in management research: Theoretical and methodological approaches and their biases. Journal of Business Ethics, 9(4-5), 267-274.

Fielden, S. L., Davidson, M. J., Gale, A., \& Davey, C. L. (2001). Women, equality and construction. Journal of Management Development, 20(4), 293-305.

Fielden, S. L., Davidson, M. J., Gale, A. W., \& Davey, C. L. (2000). Women in construction: the untapped resource. Construction Management \& Economics, 18(1), 113-121.

Flanders, M. L. (1994). Breakthrough: The Career Woman's Guide to Shattering the Glass Ceiling. ERIC.

Gale, A. W. (1994). Women in non-traditional occupations: The construction industry. Women in Management Review, 9(2), 3-14.

Gale, A. W., \& Skitmore, M. (1990). Women in the Construction Industry-A Discussion on the Findings of the Two Recent Studies of the Construction Industry Sector.

Gann, D., \& Senker, P. (1998). Construction skills training for the next millennium. Construction Management \& Economics, 16(5), 569-580.

Gayani Fernando, N., Amaratunga, D., \& Haigh, R. (2014). The career advancement of the professional women in the UK construction industry: The career success factors. Journal of Engineering, Design and Technology, 12(1), 53-70.

Ginige, K., Amaratunga, R. D. G., \& Haigh, R. P. (2007). Gender stereotypes: A barrier for career development of women in construction.

Graham, M. E., \& Hotchkiss, J. (2003). Which industries are the best employers for women? An 
application of a new equal employment opportunity index. Working Paper, Federal Reserve Bank of Atlanta.

Greed, C. (2000). Women in the construction professions: Achieving critical mass. Gender, Work \& Organization, 7(3), 181-196.

Guillaume, C., \& Pochic, S. (2009). What would you sacrifice? Access to top management and the worklife balance. Gender, Work \& Organization, 16(1), 14-36.

Heredia, E. B. (2004). Diversidad de género, igualdad de oportunidades y entornos laborales. CIRIECEspaña, Revista de Economía Pública, Social y Cooperativa, 50, 37-53.

Higgins, C., Duxbury, L., \& Johnson, K. L. (2000). Part-time work for women: Does it really help balance work and family? Human Resource Management: Published in Cooperation with the School of Business Administration, The University of Michigan and in Alliance with the Society of Human Resources Management, 39(1), 17-32.

Hossain, J. B., \& Kusakabe, K. (2005). Sex segregation in construction organizations in Bangladesh and Thailand. Construction Management and Economics, 23(6), 609-619.

Hughes, K. (1994). Women in non-traditional occupations.

Hundley, G. (2001). Why women earn less than men in self-employment. Journal of Labor Research, 22(4), 828-829. https://doi.org/10.1007/s12122-001-1054-3

Jaafar, M., Othman, R., \& Jalali, A. (2014). Main determinations of female entrepreneurs in the construction industry in Malaysia. Project Management Journal, 45(1), 76-86.

Jaiswal, R. P. (1993). Professional status of women: A comparative study of women and men in science and technology. Egully. com.

John Kolade, O., \& Kehinde, O. (2013). Glass ceiling and women career advancement: Evidence from Nigerian construction industry. Iranian Journal of Management Studies, 6(1), 77-97.

Kaewsri, N., \& Tongthong, T. (2014). Favorable female attributes in relation to career challenges of women engineers in the Thai construction industry. International Journal of Construction Education and Research, 10(3), 222-236.

Kanter, R. M. (1977). Some effects of proportions on group life: Skewed sex ratios and responses to token women. American Journal of Sociology, 82(5), 965-990.

Kramer, L. A., \& Lambert, S. (2001). Sex-linked bias in chances of being promoted to supervisor. Sociological Perspectives, 44(1), 111-127.

Langford, D., Fellows, R. F., Hancock, M. R., \& Gale, A. W. (2014). Human resources management in construction. Routledge.

Ling, F. Y. Y., \& Leow, L. (2008). Enabling knowledge flow: Retaining graduate women in the Singapore construction industry. Journal of Construction in Developing Countries, 13(2), 65-81. 
Lingard, H., \& Francis, V. (2004). The work-life experiences of office and site-based employees in the Australian construction industry. Construction Management and Economics, 22(9), 991-1002. https://doi.org/10.1080/0144619042000241444

Lingard, Helen, \& Lin, J. (2004). Career, family and work environment determinants of organizational commitment among women in the Australian construction industry. Construction Management and Economics, 22(4), 409-420.

Lu, S., \& Sexton, M. (2010). Career journeys and turning points of senior female managers in small construction firms. Construction Management and Economics, 28(2), 125-139.

Maddock, S. (1999). Challenging women: gender, culture and organization. Sage.

Madikizela, K., \& Haupt, T. (2010). Influences on women's choices of careers in construction: a South African study.

Martin, P. Y. (1996). Gendering and evaluating dynamics: Men, masculinities, and managements. Men as Managers, Managers as Men, London: Sage, 186-209.

Maume Jr, D. J. (1999). Glass ceilings and glass escalators: Occupational segregation and race and sex differences in managerial promotions. Work and Occupations, 26(4), 483-509.

McIlwee, J. S., \& Robinson, J. G. (1992). Women in engineering: Gender, power, and workplace culture. SUNY Press.

McKeen, C. A., \& Burke, R. J. (1994). The woman-friendly organization: initiatives valued by managerial women. Employee Councelling Today, 6(6), 18-25.

Morgan, C. S. (1992). College students' perceptions of barriers to women in science and engineering. Youth \& Society, 24(2), 228-236.

Ogunlana, S. O., Rost, U., Robles-Austriaco, L., \& Worawichawong, K. (1993). Women in the Thai Construction Industry. AIT Women Study Circle (AIT WSC), Bangkok, 5.

Okamoto, D., \& England, P. (1999). Is there a supply side to occupational sex segregation? Sociological Perspectives, 42(4), 557-582.

Ortiz, A. Y., Nicholls, G. M., \& Leonard, K. M. (2014). Career Stage Analysis of Women Civil Engineering Faculty Perceptions of Job Satisfaction. Journal of Professional Issues in Engineering Education and Practice, 141(3), 4014013.

Rapoport, R., Bailyn, L., Fletcher, J. K., \& Pruitt, B. H. (2002). Beyond work-family balance: Advancing gender equity and workplace performance. Jossey-Bass San Francisco, CA.

Reyes, M. M., \& Delgado, C. C. (2021). Mujeres académicas frente al techo de cristal. Un estudio de caso en educación superior. South Florida Journal of Development, 2(2), 1853-1861.

Simon, A. I. (2013). Children's perception of women in construction. 49th Associated Schools of Construction Annual International Conference, San Luis Obispo, CA. 
Toor, S.-R., \& Ofori, G. (2010). Women leaders breaking the glass ceiling in Singapore's construction industry. Journal of Professional Issues in Engineering Education and Practice, 137(1), 1-6.

Townley, B. (1989). Selection and appraisal: reconstructing social relations?, in (ed) J Storey. New Perspectives in Human Resource Management.

Watts, J. H. (2009). “Allowed into a man's world” meanings of work-life balance: Perspectives of women civil engineers as "minority" workers in construction. Gender, Work and Organization, 16(1), 37-57. https://doi.org/10.1111/j.1468-0432.2007.00352.x

Wentling, R. M. (1996). A study of the career development and aspirations of women in middle management. Human Resource Development Quarterly, 7(3), 253-270.

Wernick, E. D. (1994). Preparedness, career advancement, and the glass ceiling. Federal Publications, 128.

Whittock, M. (2002). Women's experiences of non-traditional employment: is gender equality in this area a possibility? Construction Management \& Economics, 20(5), 449-456.

Williams, C. L. (1995). Still a man's world: Men who do women's work (Vol. 1). Univ of California Press.

Wirth, L. (2001). Breaking through the glass ceiling. Women in management.

Yean Yng Ling, F., \& Pei Poh, Y. (2004). Encouraging more female quantity surveying graduates to enter the construction industry in Singapore. Women in Management Review, 19(8), 431-436. 